Bayero Journal of Pure and Applied Sciences, 11(1): 68 - 72

ISSN 2006 - 6996

\title{
ANALYSIS OF BACTERIAL URINARY TRACT INFECTION AMONG PREGNANT WOMEN IN TERTIARY HOSPITAL KATSINA
}

\author{
${ }^{*}$ Abdulkadir, B. ${ }^{1}$ and Aisha, A. S. ${ }^{1}$ \\ ${ }^{1}$ Department of Microbiology Umaru Musa Yaradua University Katsina \\ *Corresponding author: bashir.abdulkadir@umyu.edu.ng (+2348065137374)
}

\begin{abstract}
Urinary Tract Infection (UTI) is an infection caused by the presence and replication of microorganisms in the urinary tract. The aim of this study is to evaluate the distribution of UTI pathogens associated with pregnant women attending Federal Medical Center, Katsina. The research was a prospective study conducted among 126 antenatal attendees. Urine microscopy and culture technique were conducted for each participant. Statistical analysis of data was done using Graph Pad Prism Statistical software. Twenty-five out of the participants had asymptomatic bacteriuria giving a prevalence of $19.8 \%$. However age $(P=0.66)$, educational status $(P=0.19)$ and settlement $(P=0.91)$ are not statistically significant. While tribe and gestational age (trimester) are found to be statistically significant $(P=0.02)$. Staphylococcus aureus is found to be the most prevalent organism (40\%), followed by coagulase negative Staphylococcus (32\%) and the least is Eschericia coli (4\%). However, comparison between Hausa and Yoruba had shown that Hausa tribe has more chance of infected with Asymptomic bacteriuria during pregnancy and high risk than Yoruba tribe! Therefore, UTI has the potentiality to pose serious life threatening consequences when left untreated. This is more likely to be the case where access to or availability of timely and appropriate medical intervention due to inadequate numbers of health care providers.It is therefore, recommended that pregnant women should be subjected for urine laboratory screening for the detection of UTI during the first trimester and treatment follows immediately for the positive results.
\end{abstract}

Key Word: Bacteriuria, Infection, Pregnancy, and Urine culture.

\section{INTRODUCTION}

Urinary tract infections (UTIs) refer to both microbial colonization of the urine and tissue invasion of any structure of the urinary tract (Aminu and Aliyu, 2015). Bacteria are most commonly responsible although yeast and viruses may also be involved (Turay et al., 2014).

Females are believed to be more affected than males except at the extremes of life, this is because bacteria can reach the bladder more easily in women, partially due to the short and wider female urethra, and its proximity to the anus (Oleghe et al., 2014).

Available scientific information indicates that bacteria easily travel up to the urethra from the rectum and thereby causing infection, of interest, is the fact that urinary tract infections in pregnancy increases during the gestational period, beginning from the sixth week of the first trimester and peaking in the 22nd to 24th week of the second trimester (Turay et al., 2014). At this period, approximately $90 \%$ of pregnant women develop ureteral dilatation which remains until delivery, leading to increase in bladder volume and decreased bladder and ureteral tones, causing increase in urinary stasis and ureterovesical reflux (Joanna et al., 2015).

Urinary tract infections (UTIs) represent the most common bacterial infection in pregnant and non-pregnant women (Oleghe et al., 2014). Urinary tract infections can be grouped into two; complicated and uncomplicated urinary tract infections (Marcelo et al., 2014) and have been sub-grouped into acute uncomplicated cystitis, acute uncomplicated pyelonephritis, complicated cystitis and complicated pyelonephritis (Ramesh and Aggarwal, 2012). Urinary tract infections can be asymptomatic or symptomatic (Aminu and Aliyu, 2015). Urinary tract infections have been classified into 3;asymptomatic bacteriuria, cystistis and pyelonephritis (Joanna et al., 2015).

The pathogenesis of urinary tract infection involves ascending infection with coliform bacteria colonizing the perineum in susceptible women. Bacteria associated with urinary tract infection include Eschericia coli, Staphylococcus saprophyticus, Proteus and other Gram negative rods (Lawani et al., 2015). 
Special Conference Edition, November, 2018

Common symptoms associated with urinary tract infection include dysuria (painful urination) urgency (the enhanced desire to void the bladder and increased frequency of urination) (Mordi et al., 2015). Urinary tract infections have not been thought to cause significant mortality, however if left untreated or undertreated urinary tract infection have the potential for serious and life threatening sequel (Lawani et al., 2015). Possible sequela include pyelonephritis which can lead to renal scarring and sepsis (Minassian et al., 2013). Pregnancy predisposes women to developing a urinary tract infection however a broader risk factor analysis is important in assessing any additional therapeutic measure that might be required such as drainage in case of renal obstruction or abscess (Grabe et al., 2014).

Screening of pregnant women for urinary tract infections can minimize these urinary tract infections associated complications (Botto et al., 2008). Symptomatic urinary tract infections occurs in $1 \%$ to $2 \%$ of pregnancies, while asymptomatic bacteriuria has been reported in $2 \%$ to $13 \%$ of pregnant women (Grabe et al., 2008).

The factors that predispose a woman to urinary tract infections in pregnancy appear to be related to the anatomical and physiological changes in the kidney and urinary tract that occur during pregnancy (Chairman et al., 2008).

Bacteriuria during pregnancy is associated with a significant increase in the number of lowbirth-weight infants (<2500 g), low gestational age (<37 weeks), and neonatal mortality (Chairman et al., 2008).

Treatment of the bacteriuria lowers this risk, it is therefore generally recommended that pregnant women should be screened for bacteriuria by urine culture at least once in early pregnancy, and they should be treated if results are positive (Botto et al., 2008).

\section{MATERIALS AND METHODS}

\section{Study Area}

This study was carried out at Federal Medical Centre Katsina. It is located along Murtala Muhammad Way Jibia bypass Katsina, Katsina state.

\section{Study Population}

A study of pregnant women attending Federal Medical Centre Katsina was conducted from $19^{\text {th }}$ September - $4^{\text {th }}$ November 2017 with a total sample of 126.

\section{Ethical Approval}

Ethical approval was obtained from the research ethical committee of Federal Medical Centre Katsina (FMCNHREC. REG.N003/082012), also individual consent from each pregnant woman was assured of anonymity and confidentiality

\section{Sample Collection}

A total of 126 urine samples were collected in sterile universal bottles and transferred to microbiology laboratory of Federal Medical Centre Katsina. The patients were given a sterile, dry, wide-necked leak proof container and requested to provide early morning clean catch mid-stream urine. The urine sample was then immediately transferred to the laboratory for analysis. Questionnaires were used in order to obtain some demographic data's related to the patients

\section{Sample Analysis}

A method of Cheesbrough (2009) was adopted in carrying out the analysis of the urine sample. Urine specimens were collected and examined macroscopically for the appearance and microscopically for the presence of pus cells, casts as well as epithelial cells which signifies a urinary tract infection. Urine specimens were then inoculated on Blood Agar, Mac-Conkey Agar and Cystein Lactose Electrolyte Deficient (CLED) Agar and Manitol Salt Agar and incubated at $37^{\circ} \mathrm{C}$ for 24 hours under aerobic condition. After 24 hours of incubation, the culture plates were examined macroscopically and their appearance, size, color and morphology of the colonies and bacterial isolates were examined using standard biological procedures including Gram staining and biochemical tests.

\section{Data Analysis}

The data obtained were analyzed at 95\% confidence interval using Graph Pad Prism statistical software version 5.02. A P-value of less or equal to 0.05 was considered statistically significant. 
RESULTS

Table 1

Profile of Bacteria isolated from cases of significant bacteriuria Staphylococcus aureus has the highest percentage of occurrence.

\begin{tabular}{lcc}
\hline Type of micro-organisms & Number & $(\%)$ \\
\hline Staphylococcus aureus & 10 & 40 \\
Staphylococcus saprophyticus & 8 & 32 \\
Klebsiella species & 4 & 16 \\
Escherichia coli & 1 & 4 \\
Streptococcus species & 2 & 8 \\
Total & 25 & 100 \\
\hline
\end{tabular}

Table 2 shows the occurrence of asymptomatic bacteriuria in relation to age group. Age group 26-30 have the highest percentage of occurrence $(7.94 \%)$ followed by age group $21-25$ which had $(5.56 \%)$ and the least was age group 36-40 which had $(0.79 \%)$. Also when subjected to relative risk and odd ration analysis, they were found to be greater than 1 .

Table 2: Occurrence of Asymptomatic Bacteriuria in relation to age group of pregnant women

\begin{tabular}{llllll}
\hline Age-range & $\begin{array}{l}\text { Total number } \\
\text { examined }\end{array}$ & $\begin{array}{l}\text { Number of } \\
\text { positive } \\
\text { result }\end{array}$ & $\mathbf{( \% )}$ & $\begin{array}{l}\text { Number of } \\
\text { negative } \\
\text { result }\end{array}$ & (\%) \\
\hline $15-20$ & 10 & 2 & 1.59 & 8 & 6.35 \\
$21-25$ & 39 & 7 & 5.56 & 32 & 25.40 \\
$26-30$ & 36 & 10 & 7.94 & 26 & 20.60 \\
$31-35$ & 31 & 5 & 3.99 & 26 & 20.60 \\
$36-40$ & 10 & 1 & 0.79 & 9 & 7.14 \\
Total & 126 & $\mathbf{2 5}$ & $\mathbf{1 9 . 8 7}$ & $\mathbf{1 0 1}$ & $\mathbf{8 0 . 0 9}$ \\
\hline
\end{tabular}

Table 3 shows the occurrence of asymptomatic bacteriuria in relation to educational status. Those with secondary level of education had the highest percentage of occurrence $(11.90 \%)$ and the least was those with primary level of education which had (1.59\%). Also when subjected to relative risk and odd ration analysis, they were found to be greater than 1 .

Table 3: Occurrence of Asymptomatic Bacteriuria in relation to educational status

\begin{tabular}{llllll}
\hline $\begin{array}{l}\text { Educational } \\
\text { Status }\end{array}$ & $\begin{array}{l}\text { Number } \\
\text { examined }\end{array}$ & $\begin{array}{l}\text { Number of } \\
\text { positive } \\
\text { result }\end{array}$ & $\begin{array}{l}\text { (\%) } \\
\text { Pumber of }\end{array}$ & $\begin{array}{l}\text { (\%) } \\
\text { negative } \\
\text { result }\end{array}$ & \\
\hline Primary & 4 & 2 & 1.59 & 2 & 1.59 \\
Secondary & 64 & 15 & 11.90 & 49 & 38.89 \\
Tertiary & 53 & 8 & 6.35 & 45 & 35.71 \\
None & 5 & 0 & 0 & 5 & 3.97 \\
Total & $\mathbf{1 2 6}$ & $\mathbf{2 5}$ & $\mathbf{1 9 . 8 4}$ & $\mathbf{1 0 1}$ & $\mathbf{8 0 . 1 6}$ \\
\hline
\end{tabular}

Table 4 shows the occurrence of asymptomatic bacteriuria in relation to settlement. The urban settlers have the highest percentage of occurrence $(18.25 \%)$ and the least was semi- urban settlers which had (1.59\%). Also when subjected to relative risk and odd ration analysis, they were found to be less than 1 .

Table 4: Occurrence of Asymptomatic Bacteriuria in relation to settlement

\begin{tabular}{llllll}
\hline Settlement & $\begin{array}{l}\text { Number } \\
\text { examined }\end{array}$ & $\begin{array}{l}\text { Number of } \\
\text { positive } \\
\text { result }\end{array}$ & $\begin{array}{l}\text { (\%) } \\
\text { Number of }\end{array}$ & $\begin{array}{l}\text { (\%) } \\
\text { negative } \\
\text { result }\end{array}$ & \\
\hline Urban & 119 & 23 & 18.25 & 96 & 76.19 \\
Semi-urban & 7 & 2 & 1.59 & 5 & 3.97 \\
Rural & 0 & 0 & 0 & 0 & 0 \\
Total & $\mathbf{1 2 6}$ & $\mathbf{2 5}$ & $\mathbf{1 9 . 8 4}$ & $\mathbf{1 0 1}$ & $\mathbf{8 0 . 1 6}$ \\
\hline
\end{tabular}


Table 5 shows the occurrence of asymptomatic bacteriuria in relation to tribe. Hausa tribe had the highest percentage of occurrence (14.29\%) followed by lgbo tribe which had (3.17\%) and the least was Yoruba tribe which had $(0.79 \%)$. Also when subjected to relative risk and odd ration analysis, they were found to be less than 1.

Table 5: Occurrence of Asymptomatic Bacteriuria in relation to tribe of subjects

\begin{tabular}{llllll}
\hline Tribe & $\begin{array}{l}\text { Number } \\
\text { examined }\end{array}$ & $\begin{array}{l}\text { Number of } \\
\text { positive } \\
\text { result }\end{array}$ & $\mathbf{( \% )}$ & $\begin{array}{l}\text { Number of } \\
\text { negative } \\
\text { result }\end{array}$ & (\%) \\
\hline Hausa & 90 & 18 & 14.29 & 72 & 57.14 \\
lgbo & 6 & 4 & 3.17 & 2 & 1.59 \\
Yoruba & 10 & 1 & 0.79 & 9 & 7.14 \\
Others & 20 & 2 & 1.59 & 18 & 14.29 \\
Total & 126 & 25 & $\mathbf{1 9 . 8 4}$ & $\mathbf{1 0 1}$ & $\mathbf{8 0 . 1 6}$ \\
\hline
\end{tabular}

$\mathrm{RR}=1$ indicates equal rate of infection between the two groups

$R R>1$ indicates increased risk of infection for group in numerator

$\mathrm{RR}<1$ indicates decreased risk of infection for group in numerator

\section{DISCUSSION}

The bacteria isolated from urine cultures were Staphylococcus aureus(40\%), coagulase negative Staphylococcus (32\%), Klebsiella spp $(16 \%)$, Streptococcus spp (8\%) and Escherichia coli (4\%). Staphylococcus aureus was the most common uropathogen isolated in this study $(40 \%)$ which agreed with the earlier studies conducted at Benin city (Akerele et al.,2001), Illorin (Ajayi et al., 2012) and Ebonyi (Amadi et al., 2007). More so Escherichia coli was found to be the least prevalent in our study with $(4 \%)$ which is similar to a study conducted in Kano that indicated low prevalent of Escherichia coli among asymptomatic bacteriuria (Aminu and Aliyu, 2015). However it is contrary to the recent study conducted at Kenya (Adelaide et al., 2017) and other previous study conducted at South Eastern part of Nigeria (Ibezim et al., 2010) which showed Eschericia coli as their most prevalent organism.

The age group 26-30 had the highest prevalence of $7.94 \%$, followed by $21-25$ at $5.56 \%, 31-35$ at $3.99 \% 15-20$ at $1.59 \%$ and $36-40$ at $0.79 \%$ (Table 2). Age group 26-30 was more likely to develop asymptomatic bacteriuria than the other age groups due to increased risk of infection as shown by relative risk and odd ratio analysis.

Those with secondary level of education had the highest percentage of occurrence $11.90 \%$ followed by tertiary at $6.35 \%$, primary $1.59 \%$ and none was recorded in those that didn't attend school (Table 3). The level of education acquired by the samples studied has great effect on the prevalence of Asymptomatic

\section{REFERENCES}

Adelaide, Oguntu Ayoyi. Gideon, Kikuvi and Samuel, Kariuki1. Adelaide, Oguntu Ayoyi. Gideon, Kikuvi and Samuel K. Prevalence,Aetiology and Antibiotic Sensitivity Profile of Asymptomatic Bacteriuria Isolates from Pregnant Women in selected Antenal Clinic f, K. bacteriuria. Those with primary level of education have increased risk of infection than those with higher level of education as shown by odd ratio and relative risk analysis.

Those in the Urban had the highest prevalence of $18.25 \%$ followed by semi- urban at $1.59 \%$ none came from the rural region (Table 4). Although there was a low level of odd ratio and relative risk in both regions, there is also decreased rate of infection in urban areas due to the low level of relative risk. This may be because of the availability of healthy environment in the urban areas for prevention, as well as proximity to health centers, clinics and hospitals compared with the semi urban or rural areas.

Hausa tribe had the highest prevalence 14.29\%, followed by lgbo $3.17 \%$, others $1.59 \%$ and Yoruba $0.79 \%$ (Table 4.5 ). Low levels of Odd Ratio and Relative Risk in comparison between Hausa and lgbo has indicated that both the two tribes have equal chance of getting infected with Asymptomatic bacteriuria with risks of getting infected decreased in Hausa tribe. However, comparison between Hausa and Yoruba had shown that Hausa tribe has more chance of infected with Asymptomic bacteriuria and high risk than Yoruba tribe.

\section{CONCLUSION}

The prevalence of asymptomatic bacteriuria among pregnant women attending Federal Medical Center Katsina was high (19.8\%) and Staphylococcus aureus was found to be the most prevalent organism.

P. A. M. J. 2017; (2017). Prevalence,Aetiology and Antibiotic Sensitivity Profile of Asymptomatic Bacteriuria Isolates from Pregnant Women in selected Antenal Clinic from Nairobi, Kenya. The Pan African Medical Journal. 
Akerele, J. O. G. (2001). Prevalence of Asymptomatic Bacteriuria among pregnant women in Benin City, Nigeria. Public Medical Journal.

Akinlola, B. Ajayi, Charles, Nwabuisi and Olurotimi, O. F. (2012). Asymptomatic Bacteriuria in Antenatal Patients in Illorin, Nigeria. Oman Medical Journal.

Amadi, E.S., Enemuo, O.B., Uneke, C.J., O.K. Nwosu, R.A Onyeagba and Ugbogu, 0. C. (2007). Asymptomatic Bacteriuria among Pregnant Women in Abakaliki, Ebonyi State Nigeria. Journal of Medical Sciences.

Chairman, M. G., Bishop, M. C., Botto, H., Çek, M., Lobel, B., Naber, K. G., ... Tenke, P. (2008). Guidelines on The Management of Urinary and Male Genital Tract Infections. Journal of Urology.

Cheesbrough, M. (2009). District Laboratory Practice in Tropical Countries Part 2 (Second). Cambridge University Press.

Grabe M., Bartoletti R., Bjerklund and Johansen., H. (2014). Guidelines on Urological Infections. European Association of Urology.

Joanna, M., Jolanta, M., and Monika, W. (2015). Urinary Tract Infections in Pregnacy: Old and New unresolved Diagnostic and Therapeutic problems. Archives of Medical Science, 66-77.

Kani, Aminu Yamuna., Aliyu, U. U. (2015). Asymptomatic Bacteriuria in Pregnant Women in the Antenatal Booking Clinic at Aminu Kano Teaching Hospital ,. Journal of Obstetrics and Gynecology,

\section{5, 286-297.}

Lawani, Ebiodur U., Alade, Tolulope., and Oyelaran, D. (2015). Urinary Tract Infections Amongst Pregnant Women in Amassoma Southern Nigeria. African Journal of Microbiology Research, 9(6), 355-359.

Marcelo, H., Homero, B., Antonio, C., Miguel , S., and N. (2014). Uncomplicated Urinary Tract Infections in Women. European Association of Urology.

Minassian, C., Thomact S.C., William D.J., C. O. and S. L. (2013). Acute Maternal Infection and Risk of Pre-eclampsia. Journal of Medical Sciences, 8, 730747.

Mordi, R. M., Burke, M. E., Odjadjare, E. E., Onyinye, A. E., \& Umeh, J. (2015). Prevalence of Urinary Tract Infections ( UTI ) Among Pregnant Women in University of Benin Teaching Hospital ( UBTH ) Benin City , Nigeria. Diyala Journal of Medicine, 5(4), 198-204.

Ramesh , H., Aggarwal, K. (2012). Urinary Tract Infections in Women. Indian Journal of Clinical Practice, 23.

Turay, A.A., Eke, S.O., Oleghe, P.O and Ozekhome, M. . (2014). Prevalence of Urinary Tract Infections among Pregnant Women Attending Antenatal Clinic at Ujoelen Primary Health Care Centre, Ekpoma, Edo State, Nigeria. International Journal of Basic, Applied and Innovative Research, 3(1), 86-94.

Wiedmeier, J. E. (2010). Early onset neonatal sepsis. Gynaecolagia et Perinatologia ,Supplement. 